\title{
PENGGUNAAN PAIR COUNSELING UNTUK MENINGKATKAN KEMAMPUAN PERSPECTIVE TAKING SISWA
}

\author{
Eko Darminto \\ Program Studi Psikologi FIP UNESA \\ email: edmartowijoyo@yahoo.co.id \& edmartowijoyo@ gmail.com
}

\begin{abstract}
ABSTRAK
Tulisan ini menyajikan suatu gagasan konseptual tentang penggunaan pair-counseling untuk meningkatkan kemampuan perspective taking. Sejumlah penelitian membuktikan bahwa perspective taking dapat mempengaruhi perilaku sosial. Atas dasar fakta ini maka perspective taking dapat dijadikan sasaran intervensi untuk menangani berbagai gangguan perilaku seperti kekerasan pada remaja. Secara teori pair-counseling memiliki karakteristik teraperik yang tepat untuk meningkatkan kemampuan perspective taking. Sejumlah teknik yang digunakan dalam pair-counseling serta lingkungan bermainnya dipandang dapat mengembangkan kemampuan perspective taking pada anak dan remaja.
\end{abstract}

Kata Kunci: pair counseling, perspective taking, pemahaman interpersonal, perkembangan kognitif

\section{ABSTRACT}

This writing proposed conseptual idea about pair-counseling application to increase perspective taking ability. Same researches proved that perspective taking can effect social behavior. Based on that data, perspective taking can be used as intervention target to handle some behavioral disorders such as violence among teenagers. Theoritically, peer counseling has effective therapitic characteristics to upgrade perspective taking. Some techniques in pair counseling and the playing environment can develop perspective taking ability among children and teenagers.

Keywords: pair counseling, perspective taking, perspective taking, interpersonal understanding, cognitive development

\section{PENDAHULUAN}

Perspective taking atau social perspective taking - untuk bahasan selanjutnya disingkat dengan PT merupakan konstruk psikologis yang telah mengundang banyak perhatian para ahli psikologi untuk mengkaji dan menelitinya dalam hubungannya dengan berbagai gejala perilaku. Hasil-hasil kajian teoretik dan empirik PT banyak dimuat di berbagai jurnal. Minat ahli dan peneliti terhadap konstruk PT tampaknya didasarkan pada fakta teoretik dan empirik bahwa kemampuan PT dapat mempengaruhi perilaku individu baik secara langsung maupun tidak langsung. Hasil-hasil penelitian yang telah dilakukan umumnya membuktikan bahwa kemampuan PT dapat membentuk dan meningkatkan perilaku sosial positif dan menurunkan bahkan menghentikan perilaku sosial negatif. Sebagai contoh, beberapa hasil penelitian yang telah dilakukan telah membutikan bahwa kemampuan PT dapat 
meningkatkan perilaku menolong (Maner, et al., 2002), kemampuan dalam bernegosiasi (Trotschell, et al., 2011) dan memecahkan masalah interpersonal (Marsh, Sarafica, \& Barenboim, 1980), kepedulian terhadap lingkungan (Schultz, 2000), perilaku organisasional positif (Parkr, Atkins, \& Axtell, 2008) dan kepemimpinan yang efektif (Steen \& Veen, 2005).

Pengaruh positif kemampuan PT pada perilaku sosial positif tampaknya berkaitan dengan fakta bahwa kemampuan PT merupakan aspek penting dari kompetensi sosial. Individu dengan kemampuan PT tinggi cenderung menampilkan kompetensi sosial tinggi. Beberapa penelitian yang dilaporkan oleh Dawson \& Fernald (1987) telah membuktikan bahwa kemampuan PT dapat meningkatkan keterampilan sosial. Galinsky, Ku, \& Wang (2005) mengajukan suatu hipotesis bahwa dampak positif kemampuan PT pada beberapa perilaku positif disebabkan oleh karena kemampuan PT dapat membangun keterikatan dan koordinasi sosial. Hasil penelitian juga menyatakan kemampuan PT dapat membangun masyarakat demokratis (Calderon, 2011), dan menjembatani efek penolakan sosial dan perilaku altruis (Zheng Li, 2011), menurunkan penilaian stereotipe negatif (Weyant, 2007; Galinsky \& Moskowitz, 2000), prasangka (Galinsky $\& \mathrm{Ku}, 2004)$, egosentrisme (Epley, Caruso, \& Bazeman, 2006), dan kecemasan (Aberson \& Haag, 2007), bahkan gejala sichizophrenia (Sciffman et al., 2004). Hasil reviu yang dilakukan oleh Roan et al., (2009) terhadap sejumlah penelitian tentang PT juga mengkonfirmasikan temuan-temuan tersebut.

Berdasarkan pada fakta-fakta tersebut maka dalam kaitannya dengan bidang intervensi klinis atau modifikasi perilaku, kemampuan PT dapat dijadikan sebagai sasaran intervensi guna mencegah atau menghentikan berbagai bentuk perilaku sosial negatif dan mendorong perilaku sosial positif. Meskipun banyak bukti telah menyatakan dampak PT pada peningkatan perilaku sosial positif dan pengurangan perilaku sosial negatif, belum banyak penelitian eksperimen yang melibatkan siswa, khususnya di Indonesia, yang dimaksudkan untuk mereduksikan berbagai perilaku negatif siswa dan mendorong perilaku positif dengan menggunakan paradigma PT. Padahal penggunaan paradigma PT sebagai landasan untuk mengembangkan program intervensi guna mereduksikan berbagai bentuk perilaku negatif dan mendorong perilaku positif siswa dapat menjadi suatu modalitas perlakuan yang sangat menjanjikan jika diterapkan di lembaga pendidikan kita.

Hasil-hasil penelitian telah membuktikan keefektifan beberapa teknik intervensi untuk meningkatkan kemampuan PT pada subyek siswa. Sebagai contoh, video modeling dan reinforcement terbukti efektif untuk meningkatkan kemampuan PT pada anak autis (LeBalnc, Coates, \& Lancaster. 2003; Pecukonis, 1997). Penelitian lain membuktikan keefektifan teknik role playing untuk meningkatkan kemampuan PT siswa (Chalmers \& Townsend, 2008; Marsh, 1980; Pecukonis, 1997). Beberapa penulis dalam bidang PT juga merekomendasikan penggunaan videotape, case study, role play, branching exercise, \& pair share of small group discussion and exercise (Gelbach \& Metcalf, 2009), visual feedback, chair-work, dan forgiveness therapy (Day, Howells, Mohr, Schall, dan Gerace , 2008), atau suatu strategi pedagogi yg disebut "Perspectival learning"(Steen \& Veev, 2005), dan paircounseling (Karcher, 2002).

Tulisan ini hendak mengetengahkan suatu model pendekatan intervensi yang efektif guna meningkatkan kemampuan PT siswa, yakni suatu pendekatan konseling yang dilaksanakan melalui format komunikasi diadik antara dua subyek yang diformasikan secara berpasangan yang 
populer disebut dengan istilah konseling berpasangan atau pair-counseling. Model konseling ini memiliki kondisi-kondisi terapeutik yang tampak relevan dan efektif untuk meningkatkan kemampuan PT. Penggunaan pair counseling (PC) sebagai pendekatan intervensi guna meningkatkan kemampuan PT dipandang menarik untuk dikaji untuk beberapa alasan. Alasan pertama didasarkan pada fakta bahwa PC dikembangkan atau memiliki landasan teoretik yang jelas dan teori itu relevan dengan teori PT. Alasan kedua, PC memiliki struktur tujuan dan perlakuan yang jelas. Alasan ketiga, PC membangun kondisi-kondisi perubahan yang dapat memfasilitasi perkembangan kemampuan PT. Alasan keempat, PC telah terbukti efektif untuk menangani berbagai gangguan perilaku anak dan remaja.

\section{KAJIAN TEORI}

\section{Konsepsi dan Teori PT}

a. Konsepsi PT

Konsep atau konstruk pespective taking (PT) banyak ditemukan dalam literatur khususnya yang berupa artikel yang dimuat di jurnal bidang ilmu psikologi dan pendidikan. Berikut adalah beberapa contoh definisi PT yang dikutip dari beberapa tulisan. Galinsky, $\mathrm{Ku}, \&$ Wang (2005) mendefinisikan PT sebagai suatu proses membayangkan lingkungan melalui sudut pandang orang lain. Mereka memandang PT sebagai suatu proses kognitif, strategi sosial, dan perilaku yang dapat membantu individu untuk membangun ikatan sosial. Membangun keterikatan sosial itu sendiri merupakan bagian dari upaya untuk memuaskan kebutuhan untuk meiliki (need to belong) yang menjadi unsur sangat krusial untuk mendukung kesejahteraan psikologis seperti digambarkan oleh Maslow dalam dalam teorinya tentang hirarkhi kebutuhan.

Gehlbach (2004) seperti dikemukkan kembali oleh Roan et al. (2009) menyatakan bahwa PT merupakan suatu keterampilan yang mempersyaratkan kombinasi dari kemampuan kognitif dan afektif/emosional dan kecenderungan atau motivasi untuk melakukan suatu tindakan. Kemampuan ini berisikan strategi yang kita gunakan untuk membayangkan (menduga) apa yang dirasakan dan dipikirkan oleh orang lain dan persepsi mereka tentang suatu situasi. Jadi PT merupakan suatu kemampuan untuk memahami bagaimana orang lain memandang atau mempersepsi suatu situasi dan bagaimana ia akan bereaksi secara kognitif dan afektif. Dikemukakan lebih lanjut Roan bahwa PT merupakan suatu kemampuan untuk menempatkan diri kita ke dalam diri orang lain dan mengakui bahwa orang lain memiliki sudut pandang yang berbeda dengan kita. Prosesproses yang terlibat di dalam kemampuan ini berada di bawah kontol kesadaran dan dengan demikian dapat dimodifikasi melalui kesadaran dan latihan.

Trotschel et al. (2011) mengutip definisi dari Davis (1983) yang menyatakan bahwa secara umum PT merupakan suatu kemampuan kognitif untuk memaknai lingkungan dari sudut pandang orang lain dan kemampuan ini memungkinkan individu untuk dapat mengantisipasi perilaku dan reaksi orang lain. Atas dasar definisi ini maka Trotschel et al. menyatakan bahwa PT merupakan suatu mindset cognitif yang mengaktifkan seperangkat prosedur kognitif yang terarah pada kondisi psikologis orang lain. Mindset kognitif ini dapat menjadi kondisi untuk membentuk 
berbagai motif atau tujuan, misalnya mengoptimalkan hasil-hasil sendiri atau orang lain. Tentang mindset kognitif ini juga juga ditegaskan oleh Steen \& Veen (th) yang mengatakan bahwa PT merupakan komponen kognitif dari empati, sedangkan empati merupakan komponen afektif.

b. Teori PT

Terdapat beberapa teori yang menjelaskan konstruk PT yang dapat ditemukan daam literatur. Namun di antara teori-teori tersebut ada tiga yang paling sering disebut dalam literatur, yakni theory of mind yang sering disingkat dengan ToM, relational frame theory yang sering disingkat dengan RFT, dan teori pemahaman interpersonal yang juga sering disebut dengan nama teori perspective taking. Ada dua teori lain yang banyak digunakan dalam studi klasik PT yakni teori perkembangan kognitif dari jean Piaget dan teori perkembangan moral dari Laurence Kohlberg. Teori Selman dikembangkan sebagai hasil integrasi dari dua teori Piaget da Kohlberg. Berikut deskripsi garis besar dari teori-teori tersebut.

\section{(1)Theory of Mind}

Theory of Mine atau ToM tergolong teori awal yang banyak digunakan dalam penelitin PT. Teori ini cenderung praktis dan melibatkan perncangan programprogram intervensi untuk memfasilitasi dan meremediasi defisit kemampuan PT pada anakanak pengidap autis (McHugh, Barnes-Holmes, \& Maynooth, tth). Menurut ToM kemampuan PT berkembang melalui lima tingkatan pemahaman informasional (Howlin, BaronCohen, \& Hadwin, 1999) sebagai berikut:

Tingkat $\quad 1$ (PT visual sederhana). Pada tingkat ini anak

harus mengerti bahwa orang lain dapat membentuk pandangan yang berbeda dalam melihat sesuatu. Keterampilan ini dapat dikembangkan dengan cara menyajikan sebuah kartu yang memiliki gambar berbeda pada kedua sisinya. Kartu diperlihatkan kepada anak dan setiap anak hanya dapat melihat satu gambar dari satu sisi. Anak selanjutnya diminta untuk menyatakan gambar yang ia lihat dan gambar lain yang dilihat oleh anak lain (mengadopsi perspektif sendiri dan orang lain).

Tingkat 2 (PT visual kompleks). Tingkat ini berkenaan dengan kemampuan untuk mengakui bahwa orang lain dapat memiliki pandangan yang berbeda pada obyek yang sama. Kemampuan ini dapat dikembangkan melalui skenario berikut: meminta dua anak duduk saling berhadapan dan menampatkan sebuah gambar (misalnya kucing) di tengah meja yang membatasi keduanya. Dalam penataan seperti itu maka satu anak akan melihat gambar kucing dalam posisi yang benar, sedangkan anak lain melihat gambar kucing dalam posisi terbalik. Setelah disajikan gambar tersebut, anak diminta menyatakan apa yang ia lihat dan apa yang dilihat oleh temannya.

Tingkat 3 (pengetahuan
muncul dari penglihatan).
Visualisasi dinilai kurang
memainkan peran penting dalam
PT. Pada tingkat ini anak akan
memahami bahwa pengetahuan
diperoleh dengan melihat.
Skenario yang digunakan pada
tahap ini adalah dengan
menyajikan sebuah kotak kosong
kepada anak dan anak diminta


untuk menutup matanya. Ketika anak menutup matanya, sebuah benda dimasukkan ke dalam kotak. Anak kemudian ditanya tentang apa yang ada di dalam kotak. Jawaban yang benar adalah bahwa ia tak dapat mengetahui karena ia tak melihat. Selanjutnya anak diminta melihat ke dalam kotak dan ditanya apakah ia sekarang tahu apa yang ada di dalam kotak. Jawaban yang benar adalah bahwa sekarang ia tahu apa yang ada di dalam kotak karena ia telah melihat. Skenario yang sama disajikan secara berulang guna mendorong kemampuan anak untuk mengambil perspektif orang lain.

Tingkat 4 (keyakinan benar). Tingkatan ini melibatkan keyakinan yang benar dan meramalkan tindakan atas dasar pengetahuan individu. Skenario pengembangan yang digunakan adalah melalui dua skenario bermain. Pada skenario pertama ditempatkan sebuah gambar tentang orang yang sedang melakukan sesuatu di dekat mainan perahu, dan beberapa saat berikutnya, disajikan skenario kedua dengan menempatkan gambar yang identik di dekat mainan pesawat terbang. Anak kemudian diberi deskripsi dan pertanyaan: "Di pagi hari kamu melihat ada gambar orang beraktivitas di dekat perahu, tetapi kamu tak melihatnya di dekat pesawat," "Kemanakah gambar orang beraktivitas itu?" Jawaban yang benar adalah gambar orang beraktivitas itu ada di dekat perahu. Kemudian anak ditanya lagi, "Mengapa gambar itu didekat perahu?" Jawaban yang benar adalah karena anak teah melihatnya sebelumnya.
Kemudian anak ditanya lagi, "menurutmu, kamu bisa menemukan gambar itu dimana?" Jawaban yang benar adalah didekat perahu. Kemudian anak diberi pertanyaan terakhir, "Mengapa kamu berpikir bahwa gambar itu ada di dekat perahu?" Jawaban yang benar adalah karena gambar itu telah dilihat sebelumnya. Dari perspektif ToM, jawaban yang benar terhadap pertanyaan-pertanyaan tersebut menyatakan bahwa orang hanya akan mengetahui apa yang dilihat, dan akan bertindak atas dasar pengetahuannya itu (keyakinan benar).

Tingkat 5 (keyakinan salah). Tingkat ini melibatkan pengetahuan informasional yang kompleks dari ToM. Pada tingkat ini anak dibelajarkan tentang keyakinan yang salah dan perilaku yang didasarkan pada keyakinan itu. Skenario yang digunakan adalah sebagai berikut: anak diprlihatkan sebuah kotak perhiasan dan ditanya, "Menurutmu apa yang ada di dalam kotak ini?" Karena belum melihat, anak mungkin menjawab bahwa dalam kotak itu berisi perhiasan (padahal, dalam kotak itu berisi kembang gula). Kotak itu kemudian dibuka dan isinya diperlihatkan kepada anak, sambil anak ditanya, "Sebelum kita membuka kotak ini, menurutmu apa yang ada di dalamnya?" Jawaban yang benar adalah bahwa ia menduga yang ada di dalam kotak itu adalah perhiasan. Kemudian anak ditanya lagi, "Sekarang setelah kamu melihatnya, apa sesungguhnya yang ada di dalamnya?" Jawaban yang benar adalah kembang gula. Sama dengan pada tingkat 4, 
jawaban yang benar terhadap pertanyaan-pertanyaan tersebut menyatakan bahwa orang akan bertindak atas dasar keyakinannya (yang salah).

(2) Relational frame theory

Relational frame theory
(RFT) memberikan suatu
penjelasan naturalistik dan
analitik-fungsional
perkembangan (gejala) kognitif
dan bahasa (Hayes, Barnes-
Holmes, \& Roche, 2001). Teori ini memberikan suatu definisi tentang peristiwa kognitif dan bahasa dalam arti pemerolehan respon relasional. Berikut adalah deskripsi tetang RFT dalam hubungannya dengan perkembangan kemamouan PT seperti dikemukakan oleh McHugh, Barnes-Holmes, \& Maynooth (dalam Barnes-Holmes \& Cullinan, 2001):

RFT berusaha untuk menetapkan bentuk-bentuk relasional yang mewakili kinerja PT yang kompeten. Menurut RFT, perkembangan PT disokong oleh meningkatnya kompleksitas dalam kemampuan untuk memberi respon sesuai dengan tiga frame deictic berikut: "saya dan kamu," "di sini dan di sana," dan "sekarang dan nanti." Relasi deictic tersebut diyakini muncul sebagian melalui kebiasaan dalam merespon pertanyaanpertanyaan "Apa yang sedang kamu lakukan di sana?" atau "Apa yang sedang saya lakukan di sini?" Meskipun bentuk dari pertanyaan-pertanyaan tersebut seringkali sama dari berbagai konteks, lingkungan fisiknya bisa berbeda. Apa yang relatif menetap dari berbagai peristiwa tersebut adalah sifat relasional dari "Saya vs. Kamu," "Di Sini vs. Di Sana," dan "Sekarang vs. Nanti." Dalam rangkaian perkembangan kognitif dan bahasa, sifat relasional tersebut dikatakan diabstraksikan melalui belajar berbicara tentang perspektif diri dalam hubungannya dengan perspektif orang lain. Sebagai contoh, Saya selalu berasal dari perspektif di sini, dan bukan dari perpektif orang lain di sana. Untuk memahami ini kita dapat menengok kembali pada contoh skenario kemampuan PT tingkat 2 dalam perspektif ToM. Dua anak yang saling duduk berhadapan yang dipisahkan oleh sebuah meja dan diperlihatkan sebuah gambar kucing di atas meja akan memperoleh pandangan yang berbeda terhadap gambar kucing tersebut. Satu anak melihat kucing dalam posisi yang benar (berdiri), sedangkan anak yang lain melihat kucing dalam posisi terbalik. Meskipun dua anak dalam contoh ini mengamati gambar yang sama, perspektif mereka bisa berbeda. Dengan kata lain, perspektif anak dari posisi "di sini" dapat berbeda dengan perpektif anak dari posisi "di sana." Beberapa contoh lain adalah: "Saya di sini sekarang, dan kamu di sana nanti," "Sekarang jam dua dan saya di rumah (di sini dan sekarang), tetapi Erika (kamu) masih di restoran (di sana, sekarang)." Dalam contoh-contoh tersebut terdapat kata atau frase yang berfungsi menggantikan. "Erika" secara fungsional ekivalen dengan "kamu" dan "restoran" ekivalen dengan "di sana." Apa yang tampak penting dari contoh ini adalah, dari sudut pandang RFT, aktivitas relasional tergeneralisasikan dan bukan kata-kata aktual itu sendiri. 
(3)Teori pemahaman interpersonal atau teori perspective taking

Teori ini dikembangkan oleh Robert L. Selman (1980) berdasarkan hasil penelitiannya dan dengan mengintegrasikan teori perkembangan kognitif (dan moral) Piaget dan teori pekembangan moral Kohlberg (dalam Roan et al., 2011). Selman mendefinisikan pemahaman interpersonal sebagai suatu kemampuan untuk memahami situasi sosial dalam arti perspektif jamak dari individu-individu yang terlibat di dalam interaksi itu. Dengan kata lain, pemahaman interpersonal ditentukan oleh kompleksitas kemampuan PT.

Dari hasil penelitiannya Selman (1980) seperti dikemukakan oleh beberapa penulis (Karcher, 2002; Roan, 2011; ) menggambarkan sekuensi perkembangan kemampuan PT dari usia anak hingga remaja. Dikemukakannya, pada usia antara 3-6 kemampuan PT anak bersifat egosentris karena mereka tak bisa membedakan antara perspektifnya sendiri dan perspektif orang lain. Dalam situasi negosiasi, mereka ini cenderung impulsif. Pada tahapan berikutnya, usia 6-8 tahun, anak sudah mampu mengartikuliasikan perspektif subyektif mereka dan kemampuan ini disebut kemampuan PT pihak pertama $\left(1^{\text {st }}\right.$ person perspective). Pada usia antara 8-10 tahun anak sudah mampu mengembangkan kemampuan PT dua pihak $\left(2^{\text {nd }}\right.$ perspektive). Pada tahap ini anak mampu mempertimbangkan perspektifnya sendiri dan perspektif orang lain secara simultan. Tahapan kemampuan PT yang terakhir disebut kemampuan PT pihak ke tiga $\left(3^{\text {rd }}\right.$ perspective) yang berlangsung antara usia 10-12 tahun. Pada tahap ini anak mampu untuk mengambil perspektif yang lebih abstrak dalam hubungannya dengan orang lain dan mengkoordinasikan dua perspektif yang berbeda. Kemampuan PT tingkat tiga ini juga disebut perspektif bersama (we perspective), karena menyatakan kemampuan individu untuk memahami dan bertindak dalam cara yang mempertimbangkan akibat paling baik dalam hubungannya dengan orang lain. Segala tindakan yang akan dilakukan dipertimbangkan akibatnya pada hubungan dan hanya tindakan yang berakibat baik yang akan dilakukan. Pada tingkatan selanjutnya adalah kemampuan PT yang bersifat sosial yang seharusnya terbentuk setelah usia 12 tahun. Pada tingkatan ini semua anak memahami bahwa perspektif pihak ketiga dipengaruhi oleh nilai-nilai yang berlaku di dalam masyarakat luas.

Deskripsi perkembangan PT yang diusulkan oleh Selman telah diverifikasi melalui beberapa studi, seperti studi Selman dan Byrne yang meneyelidiki perkembangan PT dengan mengajukan suatu dilema moral kepada anak-anak, studi Flavell yang mengungkap kemampuan PT dalam konteks komunikasi dan pemecahan masalah sosial, penelitian Feffer \& Gourevitch yang mengggunakan pendekatan berceritera proyektif, dan penelitian Greuter yang mendalilkan perkembangan kemampuan PT sebagai hasil dari perkembangan ego (Fuhs, th). 
Terdapat sedikit kontroversi berkenaan dengan hubungan antara kemampuan kognitif dan PT. Dari teori Kohlberg jelas bahwa perkembangan kemampuan kognitif berlangsung lebih dulu sebelum perkembangan kemampuan PT. Dikaji dari perbandingan teori Piaget dan Selman juga menyatakan bahwa semakin baik kemampuan kognitif, semakin baik kemampuan PT. Namun menurut Keating \& Clark, kita tak dapat menyatakan bahwa meningkatnya kemampuan kognitif akan menyebabkan kemajuan dalam kemampuan PT karena hubungan keduanya bersifat korelasional dan bukan kausal. Namun, Walker (1980) sebagaimana juga dikutip oleh Keating \& Clark, yakin bahwa kemajuan dalam kemampuan kognitif yang berlangsung lebih dahulu dalam hubungan antara kognisi dan PT mengindikasikan adanya hubungan kausal.

Tulisan lain yang mengemuakakan suatu evaluasi terhadap teori Selman (Manly, 2006) menyatakan bahwa penelitian-penelitian umumnya mendukung beberapa pemikiran Selman tentang kemampuan PT. Hasil-hasil penelitian tersebut menyatakan bahwa: kemampuan PT menjadi kemampuan yang sangat penting dalam situasi sosial; kemampuan PT berkembang sesuai dengan tahapan-tahapan yang digambarkan oleh Selman, kemajuan perkembangan kemampuan PT tampak berkaitan dengan kemajuan dalam perkembangan kognitif dan inteligensi. Satu contoh hubungan antara kemampuan PT dengan intelegensi dilaporkan oleh Gore,
Barnes-Holmes, \& Murphy (2010) yang menyelidiki hubungan antara fungsi intelektual dengan kemampuan PT. Dalam penelitiannya mereka menemukan bahwa kemampuan PT berkorelasi positif dengan angka kecerdasan, baik pada skala verbal maupun kinerja. Anak dengan kemampuan verbal dan kinerja tinggi cenderung memperlihatkan derajad kemampuan PT lebih tinggi dibandingkan anak lain dengan kemampuan verbal dan kinerja rendah.

c. PT sebagai kemampuan yang dapat dikembangkan

Dari teori-teori yang telah dikemukakan, dapat dipahami bahwa PT bukan merupakan kemampuan bawaan tetapi kemampuan yang dapat dipelajari atau dikembagkan. Kemampuan ini sangat mungkin dapat dikembangkan di sekolah. Kemampuan PT berkembang sejalan dengan perkembangan kemampuan kognitif dan moral seperti digambarkan oleh Piaget dan Kohlberg. TOM mendeskripsikan lima tahapan perkembangan kemampuan PT dan RFT menggambarkannya dalam tiga bentuk frame relasional. Sedangkan teori pemahaman interpersonal menggambarkan lima tahapan, mulai dari egosentris, perspektif satu pihak, perspektif dua pihak, perspektif pihak ketiga, dan PT sosial mulai dari usia tiga tahun hingga 12 tahun.

Perlunya mengembangkan kemampuan PT bukan hanya karena PT merupakan kemampuan yang dapat dipelajari/dikembangkan, tetapi juga karena beberapa anak dapat mengalami hambatan dalam mengembangkan kemampuan PT karena beberapa hal. Beberapa hasil penelitian menyatakan bahwa anak- 
anak yang memperolah pengasuhan kurang baik (mistreated) tidak mampu mengembangkan kemampuan PT secepat anak lain. Manly (2006) menemukan bahwa anak belasan tahun (usia rata-rata 15 tahun) yang mengalami pengasuhan tidak baik memperlihatkan kemampuan PT sepadan dengan kemampuan anak usia sepuluh tahun. Diduga ini disebabkan oleh karena anak-anak salah asuh tersebut hanya melakukan sedikit interaksi dengan orang tuanya atau karena mereka mengamati (belajar) perilaku sosial yang buruk pada orang tuanya. Epley \& Caruso (2008) mengemukakan tiga hambatan, yaitu: kegagalan mengaktifkan proses mental untuk secara aktif berpikir tentang keadaan mental orang lain, pemeliharaan kebiasaan egosentris, dan penyesuaian yang tidak akurat karena minimnya informasi atau pengetahuan yang dimiliki. Sedangkan Epley, et al. (2004) mengemukakan bahwa hambatan dalam PT bisa terjadi karena individu mungkin cenderung overestimate dalam menilai persepsi orang lain. Sebagai contoh, seorang remaja overestimate dalam menilai respon orang lain, guru overestimate dalam menilai kejelasan kuliahnya, orang tua overestimate dalam menilai kejelasan instruksinya pada anak, dan pasangan kekasih yang overestimate dalam menilai kejernihan emosinya. Jadi, upaya intervensi perlu memerhatikan pada faktor-faktor penghambat tersebut.

d. Nilai terapeutik PT dalam membentuk perilaku positif, dan konstruktif, dan produktif

Dari hasil-hasil penelitian seperti telah dikemukakan, kemampuan PT tidak hanya dapat menghentikan berbagai bentuk aksi kekerasan, namun juga sangat postensial untuk menciptakan perdamaian masyarakat dan menciptakan pemimpian yang efektif di masa depan. Seperti telah dikemukakan pada bagian pendahuluan, bebeapa penelitian telah membuktikan bahwa kemampuan PT dapat mendorong sikap empatik, motivasi dan perilaku menolong, perilaku altruis, menurunkan prasangka dan stereotipe negatif, ambivalensi, egoisme dan egonsentrisme. Meningkatnya empati, motivasi menolog, perilaku altruis di satu sisi dan menurunnya egosentrisme, prasangka, stereotipe negatif di sisi lain berpotensi membangkitkan rasa kebersamaan, keterikatan, saling membutuhkan, dan cinta kasih yang semuanya itu membangun rasa kedamaian pada diri setiap individu.

Selman (1980, dalam Karcher, 2002) menjelaskan bahwa ketrampilan PT akan mendasari penggunaan strategi negosiasi oleh anak dan remaja dalam situasi hubungan interpersonal. Strategi ini disebut "Strategi Negosiasi Interpersonal" dan disingkat SNI. Dikemukakan oleh Karcher (2002), keterampilan PT akan mendorong pemahaman interpersonal dan pemahaman interpersonal ini menentukan kesadaran individu tentang dampak sosial dari perbuatannya. Kesadaran ini akan menjadi dasar bagi individu untuk menggunakan SNI. Sebagai contoh, PT egosentris akan mengarahkan individu untuk memperlihatkan pemahaman interpersonal yang tidak matang, seperti ketika mereka melakukan suatu tindak kenakalan dan seakan mengabaikan bahwa masyarakat umumnya menilai tindakan impulsif mereka. Anakanak egosentris cenderung impulsif dan tidak peduli dengan ramifikasi 
tindakan kenakalan mereka. Namun, anak lain yang telah mampu untuk mengkoordinasikan dua perspektif sosial secara simultan akan menyadari bahwa orang lain memiliki suatu kehidupan psikologis internal yang tak kasat mata dan tak dapat disimpulkan secara obyektif. Keadaran ini membuat anak perlu melihat norma-norma sosial guna memprediksikan suatu tindakan tertentu dan dampak dari tindakan itu.

Setiap tahapan kemampuan PT berhubungan dengan SNI. Semakin tinggi kemampuan PT yang dimiliki anak, semakin efektif anak menggunakan SNI. Dengan kata lain, semakin tinggi kemampuan PT maka ia akan lebih berhasil dalam menangani berbagai permasalahan dalam hubungan interpersonal dan dengan cara demikian mereka lebih dapat mengembangkan hubungan interpersonal yang kondusif.

Potensi kemampuan PT untuk membangun kepemimpinan selain telah dibuktikan melalui hasil penelitian seperti telah dikemukakan, dapat pula dijelaskan melalui suatu penalaran logis. Pemimpin yang efektif harus dapat memahami perspektif komunitas yang dipimpinnya dalam arti kebutuhan, harapan, pikiran, perasaan, dan tindakannya, di samping mampu menyampaikan perspektifnya sendiri secara akurat kepada komunitas yang dipimpinya sesuai dengan level kemampuannya. Untuk dapat melakukan ini dengan baik maka seorang pemimpin memerlukan kemampuan untuk mengambil perspektif orang lain. Seorang profesor sosiologi di Pitzer College, Jose Calderon (2011), mengungkapkan bahwa dari pengalamannya ia memperoleh pemahaman bahwa kemampuan seseorang untuk mengkomukasikan perspektif dirinya mempengaruhi kemampuannya untuk berpartisipasi di dalam masyarakat, dan dengan cara itu ia akan memiliki akses untuk memasuki kekuasaan. Ia juga mengakui bahwa berkat gurunya yang mampu mengambil perspektif dirinya sebagai siswa di sekolah Amerika yang mengalami penindasan karena memiliki identitas sebagai warga pendatang dari Meksiko yang terpinggirkan, dan dirinya yang bisa mengambil perspektif gurunya, maka ia bisa menjadi seorang profesor. Ia juga mengungkapkan bahwa Barrack Obama bisa menjadi pemimpin yang berhasil karena kemampuannya yang tinggi dalam mengambil perspektif orang lain, khususnya dengan siapa ia bekerja. Dengan memahami perspektif, bahasa, dan budaya orang lain maka Barack Obama tak hanya berhasil dalam berpartisipasi dalam masyarakat yang demokratik, tetapi ia juga lebih mampu memahami dirinya sendiri, sejarah keluarganya, serta bahasa, budaya, dan perspektif anggota masyarakat dalam lingkungan kerja dan kehidupannya. Calderon juga menegaskan bahwa melalui PT maka kita dapat memahami dan menghargai setiap perbedaan dalam rangka menemukan kebersamaan. Reason (2011), juga menegaskan bahwa untuk dapat menjadi pemimpin yang efektif maka seseorang harus mampu belajar dari perspektif orang lain.

Meskipun belum ada penelitian berkenaan dengan pengaruh kemampuan PT pada keberhasilan akademik, secara teoretik kemampuan mengambil perspektif orang lain juga memungkinkan anak didik siswa dapat mencapai keberhasilan di sekolah. Siswa yang memiliki kemampuan PT yang tinggi tentu akan lebih mudah memahami 
bacaan, memahami instruksi tertulis dari suatu tugas atau yang diberikan secara lisan oleh guru, dan dengan demikian ia dapat menyelesaikan tugas-tugas dengan benar. Demikian pula, siswa yang memiliki kemampuan PT tinggi akan memungkinkan siswa dapat melakukan suatu interaksi sosial yang efektif dan menghindari konflik dengan teman-teman di sekolahnya, dengan gurunya, dan dengan orang tua atau keluarganya. Meningkatnya interaksi sosial dan teiadanya konflik antara siswa dengan orang-orang disekelilingnya, baik di rumah, di sekolah, atau di lingkungan yang lebih luas, akan menjadi suatu iklim yang kondusif bagi siswa untuk belajar dan mengembangkan dirinya.

Beberapa ahli juga telah memperlihatkan hubungan logis antara kemampan PT dengan keberhasilan belajar dengan cara melihat hubungan antara kualitas kinerja akademik dengan keterampilan sosial atau yang juga sering disebut dengan istilah kompetensi sosial. Keterampilan sosial menjadi salah satu faktor yang mempengaruhi kualitas kinerja akademik (Steedly, et all., 2008). Keterampilan sosial adalah komponen perilaku yang membantu individu untuk memahami dan menyesuaikan diri dengan berbagai lingkungan sosial. di dalam keterampilan sosial terkandung beberapa dimensi, salah satunya adalah kemampuan PT (Spence, 2003; Epley, Morewedge, \& Keysar, 2004). Para ahli psikologi sekolah yang tergabung dalam asosiasi nasional psikolog sekolah di Amerika (2002) juga telah mengakui bahwa keterampilan sosial merupakan faktor kritis untuk mendukung keberhasilan hidup, karena ia membuat individu mengetahui apa yang harus dikatakan, mengetahui bagaimana membuat keputusan yang baik, dan mengetahui bagaimana bertindak secara tepat dalam berbagai situasi. Derajad keterampilan sosial ini akan mempengaruhi kualitas kinerja akademik, perilaku, hubungan sosial, hubungan dalam keluarga, dan keterlibatan dalam kegiatan ekstrakurikuler di sekolah. Peserta didik yang memiliki keterampilan sosial tinggi cenderung lebih mampu membangun lingkungan sekolah yang aman dan positif, menangani tekanan dari berbagai peristiwa belajar dan kehidupan, menemukan cara terbaik guna menangani frustrasi dan agresi, membangun tanggung jawab pribadi untuk membangun lingkungan sekolah yang aman untuk belajar. dapat dikatakan bahwa peserta didik dengan kompetensi sosial tinggi cenderung mampu untuk menciptakan lingkungan belajar yang kondusif guna mendorong keberhasilan belajarnya di sekolah. Atas dasar ini maka banyak ahli yang merekomendasikan pentingnya memberikan program pelatihan keterampilan sosial di sekolah guna menangani kegagalan akademik dan berbagai bentuk perlaku menyimpang lain seperti kecanduan rokok, mariyuana, dan aktivitas seksual (Ellickson, 1997). Pelatihan dalam kemampuan PT menjadi salah satu materi penting dalam program pelatihan keterampilan sosial di sekolah. Seperti dikemukakan oleh Larson (1989), program-program pelatihan keterampilan sosial menekankan pada kendali impuls, pemantauan diri, pengambilan perspektif orang lain, dan pemecahan masalah). Atas dasar hal tersebut maka pelatihan kemampuan PT di 
sekolah dapat dipandang sbagai suatu program yang bermanfaat.

Dari semua yang telah dikemukakan, menegaskan perlunya mengembangkan kemampuan PT untuk para siswa di sekolah dalam rangka mencegah terjadinya tindak kekerasan dan membangun rasa kedamaian, meningkatkan kinerja akademik, dan menciptakan pemimpin yang efektif di masa depan. Penerapan program pelatihan PT untuk siswa di sekolah juga diharapkan dapat membangun rasa tanggung jawab pribadi dan sosial yang dapat mengeliminasi kebiasaan buruk lain di luar tindak kekerasan seperti menyontek, menyalahgunakan obat dan alkohol, dan pergaulan bebas. Pengembangan kemampuan PT tentu akan menjadi modalitas intervensi yang sangat bermakna untuk dijadikan sebagai pendekatan dalam rangka menangani berbagai masalah perilaku sosial yang melibatkan generasi muda atau kaum terpelajar untuk saat ini.

2. Penggunaan Pair-Counseling untuk Mengembangkan Kemampuan PT

a. Konsepsi Pair-Counseling

Dari sejumlah literatur yang dikaji (Karcher, 2002, Karcher \& Lewis, 2002; Selman \& Cohen, 1990) dapat diperoleh deskripsi bahwa pair counseling - untuk bahasan selanjutnya disingkat PC merupakan suatu bentuk intervensi yang digunakan untuk membantu anak dan remaja belajar keterampilan sosial yang efektif seperti keterampilan berteman, membangun dan mempertahankan hubungan abadi, dan melakukan negosiasi yang lebih efektif melalui suatu hubungan konseling yang bersifat perkembangan dan diadik. Arti perkembangan dalam konteks ini menunjuk pada digunakannya pendekatan perkembangan sebagai landasan kerangka kerja konseptual. Sedangkan arti diadik menunjuk fakta praktis bahwa dalam proses konseling konselor membantu konseli melalui pasangan-pasangan. Dua anak dipasangkan dalam suatu hubungan konseling dan dibantu oleh konselor melakukan berbagai aktivitas yang terpusat pada lingkungan bermain untuk mencapai interaksi sosial yang matang.

PC sesungguhnya merupakan hasil inovasi (pengembangan) dari pair terapy yang sudah berkembang lebih dahulu selama hampir tiga dasa warsa dalam bidang psikologi klinis dan psikologi perkembangan. Pair terapy adalah suatu modalitas perlakuan psikososial yang didasarkan pada pendekatan perkembangan untuk menangani anak dan remaja yang mengalami gangguan emosi dan perilaku tergolong akut melalui suatu terapi berjangka waktu panjang (Karcher, 2002). Terdapat beberapa persamaan dan perbedaan antara pair therapy dan PC. Persamaannya adalah bahwa keduanya merupakan terapi bermain dengan cara membentuk pasangan dari dua anak. Keduanya mengintegrasikan dinamika dan praktek yang terpusat pada anak, dengan fokus pada situasi di sini dan sekarang dan pada pengembangan keterampilan PT, pemerolehan strategi neosiasi interpersonal yang sehat, dan pengembangan keterikatan sosial antara dua anak. Pair therapy dan PC dapat dibedakan dilihat dari tingkat kontrol yang diberikan oleh terapis/konselor dalam sesi-sesi perlakuan., dalam memfasilitasi aktivitas bermain, dan dalam mengkonseptualisasikan masalah anak.

PC telah banyak digunakan untuk membantu anak dan remaja yang memiliki masalah sosial seperti 
pemalu, agresif, dan menarik diri. PC memberikan kesempatan dan konteks sosial-interpersonal yang suportif kepada anak untuk menguji dan mereviu strategi-strategi interaksi sosial yang lebih efektif. Dengan kata lain, dalam PC anak dibelajarkan dan dodorong untuk mempraktekkan keterampilanketerampilan yang efektif untuk membangun dan menjaga hubungan akrab dengan kelompoknya. Jadi, PC merupakan metode intervensi yang sangat cocok untuk anak dan remaja yang kurang memiliki keterampilan sosial, masalah hubungan pertemanan atau hubungan sosial, menarik diri, dan terisolir.

b. Formulasi teoretik

Sebagaimana dikemukakan oleh pengembang PC, Michel J. Karcher (Karcher, 2002), PC didasarkan pada asumsi bahwa banyak permasalahan anak dan remaja berkaitan dengan kurangnya keterampilan sosial dan ketidakmampuan untuk membangun hubungan baik dengan orang lain. Kegagalan dalam membangun hubungan disebabkan karena individu gagal dalam memahami orang lain atau gagal dalam mengembangkan pemahaman interpersonal. Jadi, individu bisa memahami dengan baik orang lain dalam situasi sosial-interpersonal, maka konflik atau permasalahan tidak akan muncul. Sebaliknya mereka dapat saling memahami dan mengembangkan hubungan yang saling memuasakan.

Tidak berbeda dengan Selman, Karcher mendefinisikan pemahaman interpersonal sebagai suatu kemampuan untuk memahami situasi sosial dalam arti perspektif jamak dari individu-individu yang terlibat. Dengan kata lain pemahaman interpersonal ditentukan oleh kompleksitas kemampuan PT individu, atau kemampuan suatu untuk menerapkan keterampilan PT dalam situasi sosial. Atas dasar ini maka PT dipandang sebagai kemampuan yang inti untuk memahami pikiran, kebutuhan, dan keyakinan individu lain dan atas dasar ini maka PT akan menyokong landasan bagi hubungan manusia yang efektif. Inilah yang menjadi dasar dari penggunaan teori PT dalam praktek PC.

Asumsi lain yang mendasari PC, seperti dikemukakan oleh Karcher (2002), bahwa upaya terapeutik untuk membantu meningkatkan tingkat kematangan sosial anak, khususnya pada kemampuan untuk memahami orang lain secara akurat dan efektif, dan membuat respon secara tepat terhadap perspektif orang lain akan memungkinkan terhindar dari alinasi, penolakan, isolasi, depresi, dan mencegah mereka dari tindakan agresif dan berprestasi di bawah potensi (underachievement). Asumsi tersebut antara lain didasarkan pada pernyataan Schultzc \& Selman (1989) dan Selman et al. (986) bahwa program intervensi untuk mendorong penguasaan keterampilan PT dapat membantu anak lebih mudah memahami orang lain dan dengan cara demikian akan meningkatkan kesehatan psikologisnya.

Berbagai permasalahan anak bersumber pada kurangnya atau tidak adanya kesempatan untuk mengembangkan keterampilan sosial secara memadai. Tanpa kesempatan untuk mempraktekan pikiran dan tindakan yang lebih matang, maka anak akan tetap tidak memiliki kematangan sosial. Tentang hal ini juga teah dikemukakan oleh Epley \& Caruso (2008) seperti telah dikemukakan dalam bagian teori PT, 
bahwa anak dapat mengalami hambatan dalam mengembangkan kemampuan PT pada tingkat tinggi karena mereka tidak mengaktifkan atau tidak mempraktekkannya. Berkaitan dengan ini, PC dikonstruksikan sebagai suatu strategi untuk membantu anak mempraktekkan keterampilan tersebut.

c. Implementasi

Jika pair-therapy umumnya diterapkan dalam berbagai seting yang luas dan dengan durasi yang panuang dan kurang terstruktur, PC dirancang secara khusus untuk diterapkan di sekolah dengan durasi nyang pendek dan lebih terstruktur. Meskipun tak tertutup kemungkinan PC diterapkan di luar sekolah. Dalam penerapannya di sekolah, tujuan umum PC adalah membantu anak belajar menjadi teman yang baik, membangun dan mempertahankan hubungan yang lestari, dan membuat nogosiasi yang efektif dengan orang lain (Selman \& Schultz (1990). Jadi tugas konselor PC adalah membantu anak untuk mengelola keakraban dan kemandirian dalam situasi hubungan dengan menerapkan keterampilan sosial yang tepat sesuai dengan usianya. Tujuan ini dicapai melalui aktivitas-aktivitas perkembangan yang melibatkan permainan dalam kelompok dan refleksi diri yang mendorong pemahaman dan keterampilan sosial. Salah satu keterampilan sosial itu adalah kemampuan PT.

PC menyediakan tiga perangkat teknik yang potensial digunakan untuk membantu perkembangan PT, yakni: empowering, linking, dan enabling. Karcher (2002) menyebut ketiga tenik tersebut sebagai bentuk teinik atau intervensi perkembangan. Untuk mengembangkan kemampuan PT, ketiga teknik tersebut digunakan oleh konselor untuk membantu setiap pasangan subyek bekerja sesuai dengan tingkat kematangan sosial dan perkembangannya, mulai dari tngkatan PT terendah (egosentris) menuju tingkatan paling tinggi (perspektif orang ketiga). Berikut adalah penggunaan masing-masing teknik dalam proses konseling:

- Teknik empowering digunakan untuk membantu subyek mengembangkan kemampuan PT dari tingkat 0 (egosentris) ke tingkat 1 (perspektif satu pihak yang bersifat subyektif). Ini dilakukan dengan cara mendorong subyek mengartikulasikan keyakinan, keinginan, tujuan, dan perasaanya sendiri.

- Teknik linking digunakan untuk membantu subyek menggabungkan perspektif dirinya dengan perspektif orang lain, yakni membantu pasangan untuk mengkoordinaksikan perspektif mereka. Jadi teknik ini digunakan oleh konselor untuk membantu subyek berkembang dari kemampuan PT tingkat 1 menuju kemampuan PT tingkat 2 (perspektif dua pihak). Terjadinya koordinasi perspektif memungkinkan pasangan untuk bekerja sama membuat keputusan tentang tindakan apa yang paling tepat untuk merespon situasi/stimuli.

- Teknik enabling digunakan untuk membantu pasangan melihat akibat jangka panjang dari tindakan individual pada hubungan bersama/kolektif (membantu pasangan mengambil perspektif pihak ketiga; aau membantu pasangan beralih dari kemampuan PT tingkat 2 ke kemampuan PT tingkat 3). 
Pembelajaran/pelatihan

keterampilan dan peralihan dari keterampilan yang lebih rendah menuju keterampilan yang lebih tinggi melalui ketiga teknik berlangsung dalam suasana bermain. Aktivitas bermain dalam PC berfungsi untuk mendorong perkembangan kognitif, khususya untuk mengembangkan kemampuan PT dan pemahaman interpersonal. Jenis permainan pertama yang dipilih perlu dipertimbangkan atas dasar kemampuannya untuk memfasilitasi proses-proses ekspresi diri yang dinamis (misalnya proyeksi), bermain fantasi, dan permainan simbolik spontan (Karcher, 2002). Jenis-jenis permainan itu misalnya adalah boneka, cerita lucu, atau magic-ball (dalam dunia anak Amerika, untuk di Indonesia perlu dicarikan jenis yang sepadan). Jenis permainan lain juga harus tersedia sehingga anak-anak tidak merasa dipaksa untuk melakukan aktivitas tertutup yang membuat mereka merasa tidak nyaman dalam situasi kelompok yang belum akrab. Untuk meningkatkan efek pelatihan, penerapan ketiga teknik PC dapat dibarengi dengan satu atau lebih teknik-teknik modifikasi dari pendekatan kognitif-perilaku,

Ada tiga jenis permainan lain yang secara khusus digunakan untuk memfasilitasi anak berkembang dati fase-fase keterampilan PT. Jenis yang pertama berupa permainan atau aktivitas yang bersifat fisik, impulsif, misalnya bermain bola basket. Permainan ini digunakan untuk memfasilitasi terjadinya peningkatan dari kemampuan PT tingkat 0 menuju tingkat 1. Perangkat permainan kedua, digunakan untuk memfasilitasi peralihan dari kemampuan PT tingkat 2 ke tingkat 3 , berupa permainan yang berbasis (memiliki) aturan sederhana yang memungkinkan anak merasa kompeten dalam mengkoordinasikan perspektif dan perilaku mereka. Permainan-permainan ini mengandung aktivitas yang memungkinkan anak-anak berbicara satu sama lain, memperdalam hubungan, dan berbagi pengalaman secara akrab. Perangkat permainan ketiga, digunakan untuk memfasilitasi terjadinya peningkatan kemampuan PT dari tingkat 2 ke 3, adalah jenis permainan yang dapat menumbuh kembangkan pertemanan yang akrab an mendalam. Pemainan ini harus mampu mendorong anak untuk saling membuka diri dan saling berceritera satu sama lain, memecahkan amsalah bersama, dan merasa nyaman dalam kebersamaan mereka.

3. Analisis dampak positif PC pada perkembangan kemampuan PT

Memperhatikan bahwa PC didasarkan pada pendekatan perkembangan dan menekankan pada aktivitas-aktivitas bermain dalam mendorong belajar keterampilan PT dari tingkat rendah (egosentris) ke tingkat matang (perpektif pihak ketuga) dampak PC pada perkembangan PT dapat dijelaskan melalui teori perkembangan kognitif dan teori tentang bermain. Seperti dikemukakan oleh Selman (1980) dan (O'Conor, 1991) yang dikutip oleh Karcher (2002), anak-anak berkembang melalui aktivitas bermain. Dikemukakan oleh Karcher, teori-teori terapi bermain dan perkembangan kognitif menyatakan bahwa anak-anak berkembang secara sosial dan emosional ketika mereka mampu untuk memainkan permainan yang membuat mereka memperkembangkan kontrol terhadap impulse fisik. Permainan dapat membantu anak untuk mengekspresikan perasaan secara tidak langsung, 
membuat anak merasa kompeten dan percaya diri. Bermain juga dapat membangun hubungan yang akrab, mendorong pengetahuan, praktek, dan penerapan keterampilan sosial yang lebih matang. Setiap permainan dan aktivitas bermain yang digunakan dalam PC memiliki fungsi yang berkaitan dengan teori perkembangan kognitif atau teori terapi bermain.

Dalam teori psikoanalitik, seperti dikemukakan oleh Boucher dan Armey (tth), permainan dapat berfungsi sebagai katub katarsis. Dalam hal ini Freud yakin bahwa permainan dapat membantu anak melepaskan perasaanperasaan negatif yang disebabkan oleh peristiwa traumatik dan menggantinya dengan peristiwa yang lebih positif; dalam arti bahwa permainan dapat membantu anak menjadi paham tentang situasi yang menyakitkan dan menemukan cara untuk menggantinyakan perasaan-perasaan tidak senangnya dengan perasaan senang (melalui bermain). Permainan dapat membantu anak menguasai pikiran-pikiran an tindakannya, dan belajar menginterpretasikan pengalamannya. Tentu saja, ketika anak mulai menyatakan kerentanannya terhadap dunia, permainan dapat membantu mereka untuk mereduksikan perasaan tersebut. Ahli psikoanalis lain, Erikson, menyatakan bahwa permainan dapat menyokong perkembangan psiklogis dan sosial anak. Dalam tahuntahun pertama kehidupannya, anak menggunakan keterampilan sensosri dan motorik untuk mengekplorasi (menguasai) tubuh mereka. Dalam tahun kedua, kemampuan kognitif mereka berkembang dan mereka dapat memanipulasikan obyek di sekelilingnya. Aktivitas berain dapat membantu anak mengembangkan harga diri (self-esteem) dan perasaan mampu untuk menguasai obyek. Secara berangsur-angsur, setelah mamou menguasai obyek, anak mampu menguasai interaksi sosial dengan anak lain dalam kelompok bermainnya.

Boucher dan Armey juga mengemukanan pandangan Piaget tentang permainan. Piaget, ahli yang terkenal dalam bidang perkembangan kognitif, memandang permainan (dan bermain) menjadi alat utama untuk mendorong belajar karena melalui bemain anak dapat memperoleh pengalaman baru dalam melakukan aktifitas fisik dan mental dalam menangani lingkungannya. Piaget memiliki keyakinan bahwa orang mengubah cara mereka berpikir dan bertindak dan agar dapat beradaptasi dengan lingkungannya dan bahwa adaptasi seperti itu adalah sangat penting bagi perkembangan fisik dan intelektual. Dalam teori Piaget, perubahan dalam bermain dalam setiap tahapan perkembangan berjalan paralel dengan perkembangan kognitif dan emosional. Perubahan ini memungkinkan anak menjadi lebih mampu untuk mempraktekkan pikiran dan tindakan yang dapat diterima oleh masyarakat sehingga mereka dapat bertindak secara tepat dalam berbagai situasi sosial yang dihadapinya. Perbedaan macam permainan menuntut perbedaan dalam tingkat kemampuan kognitif. Inilah yang menjadi alasan mengapa kita dapat menemukan perbedaan tipe permainan dalam setiap tahapan perkembangan kognitif.

Dikemukakan pula oleh Boucher dan Armey tentang peran permainan pada perilaku dalam teori sosio-kultural Vigotsky. Alam hal ini Vgotsky yakin bahwa permainan dapat menjadi alat bagi otak untuk membantu anak menguasai perilakunya. Teori ini menyatakan bahwa fungsi bermain adalah membantu anak mengembangkan pengendalian diri, mengembangkan kemampuan untuk memisahkan antara pikiran dan 
tindakannya, dan mengembangkan keterampilan yang dibutuhan untuk memperoleh fungs kognitif yang lebih tinggi. Diconthkan, ketika anak membuat sebuah mobil-mobilan dari bahan kardus atau balok, ia sedang belajar untuk memisahkan pikiran atau imejnya tentang mobil (permainan) dari mobil aktual, atau sedang berusaha untuk mengkoseptualisasikan atau merepresentasikannya. Pemisahan antara dunia aktual dan duia simbolik, antara pikiran dan tindakan, mempersiapkan anak untuk berkembang memasuki kemampuan berpikir abstrak. Perilaku anak tidak dikendalikan ole obyek, tetapi oleh pikiran simboliknya. Permainan dapat membantu anak mencobakan pikiran dan perilaku yang berbeda, mempetakannya ke dalam dunia nyata, dan dengan cara itu akan memampukan anak untuk menggunakan fungsi mental pada taraf yang lebih tinggi (berpikir abstrak) guna memantau dan memanipulasikan pikiran dan gagasan tanpa referensi langsung dunia nyata. Oleh karena itu bermain merupakan strategi pendidikan yang penting untuk memfasilitasi perkembangan kognitif, sosialemosional, motorik dan bahasa anak.

Hughes (2003) mengemukakan suatu rangkuman hasil-hasil penelitian tentang dampak bemain pada perkembangan anak. Hasil-hasil penelitian tersebut menyatakan bahwa bermain memampukan anak untuk: mengerti lingkungannya, mengembangkan pemahaman sosial dan budaya, menyatakan perasaan dan pikirannya, mempraktekkan pikiranpikiran fleksibel dan divergen, menamukan dan memecahkan masalah nyata, belajar mempertimbangkan perspektif orang lain, melakukan negosiasi dengan teman, mengembangkan kendali diri, mengembangkan keterapilan bahasa dan percakapan, dan meningkatkan perkembangan motorik an otak. Hasilhasil penelitian yang menyatakan hal yag sama juga dikemukakan oleh Isenberg dan Jalongo (2006).

Dari apa yang dikemukakan tersebut dapat disimpulkan bahwa bermain dengan permainan dapat meningkatkan perkembangan fisik, sosial-emosional, intelektual, an bahasa. Secara khsus, permainan atau bermain dapat mendorong kemampuan PT anak. Selanjutnya kerangka pikir ini dapat diringkaskan ke dalam bagan berikut.

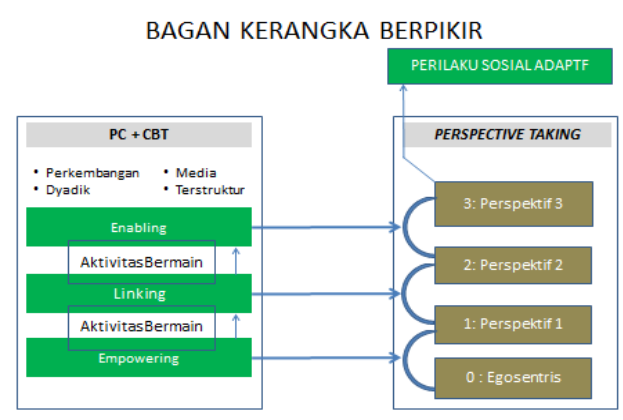

\section{KESIMPULAN}

Kemampuan dalam mengambil perspektif orang lain (perspective taking) telah menjadi konstruk psikologis yang menarik perhatian banyak ahli psikologi untuk mengkaji dan menelitinya. Minat ini didasarkan pada fakta bahwa kemampuan PT telah terbukti secara empiris untuk mendorong perilaku sosial positif dan menurunan perilaku sosial negatif. Temuan-temuan tersebut ditambah dengan dukungn teori-teori PT, paradigma PT dapat digunakan untuk menangani berbagai permasalahan atau gangguan perilaku pada anak dan remaja. Dengan kata lain, untuk menurunkan gangguan perilaku pada anak dan remaja dapat dilakuka dengan meningkatkan kemampuan PT mereka. Pendekatan intervensi tidak langsung ini lazim disebut pendekatan perkembangan. Pendekatan perkembagan adalah suatu model intervensi untuk mengubah perilaku individu yang dilakukan dengan cara 
memodifikasi faktor-faktor yang mempengaruhi perilaku. Berbagai metode intervensi telah banyak diuji keefektifannya untuk mengembangkan kemampuan PT subyek. Pair-Counseling atau PC merupakan suatu metode konseling yang memiliki karakteristik unik untuk membeajarkan kemampuan PT namun belum banyak dilakukan, bahkan di Indonesia belum dilakukan. PC dapat menjadi metode konseling yang efektif untuk meningkatkan kemampuan PT melalui tiga teknik: empowering, linking, dan enabling. Teknik empowering digunakan untuk membantu subyek berkembang dari kemampuan PT tingkat 0 menuju tingat 1 ; teknik linking digunakan untuk membantu subyek beralihdari kemampuan PT tingkat 1 ke tingkat 2, dan teknik enabling digunakan untuk membantu subyek mengembangkan kemampuan PT dari tingkat 2 ke 3 . Penerapakan ketiga teknik tersebut berlangsung dalam situais bermain.

Untuk memperbesar efek, maka penerapan ketiga teknik tersebut dapat dikombinasikan dengan teknik-teknik kognitif-perilaku seperti penguatan, pemodelan, bermain peran, modifikasi kognitif dan tugas rumah.

\section{DAFTAR PUSTAKA}

Barry, T., \& Lochan, J.E. (2004). Aggression in Adolescents: Strategies for parents and Educators. National Association of School Psychologist.

Clayton, C.J. , Ballif-Spanvill, B., \& Hunsaker, M.D. (2001). Preventing violence and teaching peace: A review of promising and effective antiviolence, conflict resolution, and peace programs for elementary school children. Apllied and Preventive Psychology, 10, pp. 1-35.

Day, A., Howells, K., \& Mohr, P. (2008). The Develoment of CBT Programmes for Anger: The Role of Interventions to Promote Perspective
Taking Skills. Behavioral and Cognitive Psychotherapy, 36, 299312.

Epley, N., Morewedge, C.K., \& Keysar, B. (2004). Perspective taking in children and adults: Equivalent egocentrism but differential correction. Journal of Experimental Social Psychology, 40, 760-768.

Epley, N., Caruso, E, M., \& Bazerman (2006). When perspective taking increases taking: Rective egoisme in social interaction. Journal of Peronality and Social psychology, 91, no. 5., 872-889.

Epley, N., \& Caruso, E,M. (2008). Perspektive-taking: Misstepping other's shoes. Handbook of Imagination and mental simulation.

Nicholas Epley, N., Caruso, E.M., \& Bazerman, M.H. (2006). When Perspective Taking Increases Taking: Reactive egoism in Social Interaction. Journal of Personality and Social Psychology, 2006, Vol. 91, No.5, pp. 872-889

Galinsky, A.D., Ku, G., \& Wang, C.S. (2005). Perspektive -Taking and self-other overlap: Fostering social bons and facilitating social coordination. Group Pocess \& Intergroup Relations, 8, 109-124.

Galinsky, A.D., \& Moskowitz, G.B. (2000). Perspective Taking: Decreasing Stereotype Expression, Stereotype Accessibility, and InGroup Favoritsm. Journal of Personality and Social Psychology, 2000, Vol. 78, No. 4, pp. 708-724.

Gore, N.J., Holmes, Y.B., \& Murphy, G. 2010. The Relationship between Intellecctual Functioning and Relational Perspective Taking. International Journal of Psychology and Psychological Therapy, 2010, Vol. 10, No. 1, pp. 1-17

Hackney, H.L., \& Cormier, L.S. (2001). The Professional Counselor. A 
Process Guide to Helping. Boston: Allyn \& Bacon.

Harton, J.K. (2008). Pair Counseling for High School Students: Improving Friendship Skills, Interpersonal Relationship, and Behavior among Aggressive and Withdrawn Adolescence. International Journal of Play Therapy, 2008

Hughes, F. (2003). Sontaneous play in the $21^{\text {st }}$ century. In O. Saracho \& Spodek (eds). "Contemporary Perspective on play early childhood education. Greenwich, CT: Infomation Age Publishing.

Karcher, M.J. (2002). The principles and practice of pair-counseling: a dyadic developmental. Play therapy for agressive, withdrwn, and socially immature youth. International Journal of Play Therapy, 11, 121147.

Karcher, M.J. 2002. The Principles and Practice of pair Counseling: A Dyadic Developmental Play Therapy for Aggressive, Withdrawn, and Socially Immature Youth. International Journal of Play Therapy, 11 (2), 121-147.

Karcher, M.J., \& Lewis, S.S. (2002). Paircounseling: The effect of a dyadic evelopmental play therapy on interpersonal understanding and externalizing behaviors. International Journal of Play Therapy, 11, 19-41.

Karcher, M.J. tth. Pair Counseling Basics: Excerpts from the Pair Ciunseling manual. Madison: Departement of Counseling Psychology The University of Winconsin.

LeBlanc, L., Coates, A, M., \& Lancaster, B.M. (2003). Using Video Modeling and Reinforcement to Teach Perspective Taking Skills to Children with Autism. Journal of Applied Behavioral Analysis, 2003, No. 2, $36,253-257$
Lerner, R.M. \& Hultsch, D.F. (1983). Human Development. A Life Span Perspective. New York: McGrawHill Book Comapany.

Mandar, H.A. (2012). "Program Bimbingan Pribadi Berdasarkan Profil Perilaku Agresif Siswa Sekolah menengah Atas" (Skripsi). Universitas Pendidikan Indonesia.

Maner, J.K., Luce, C.L., Neuberg, S.I., Cialdini, R.D., Brown, S., \& Sagarin, B.J. (2002). The Effect of Perspective Taking on Motivations for Helping: Still No Evidence for Altruism. Personality and Social Psychology Bulletin, Vol. 28, No. 11, November, 2002, pp. 1601-1610.

O'Brien, Konrtah, S.H., Gruhn, D., \& Hagen, A.L. (2010). Empathic Concern and Perspective Taking: Linier anda Quadratic Effects of Sge Across the Adult Life Span. The Journal of Gerontology, Series B: Psychological Sciences and Social Sciences, doi: 10, 1093/geromb/gbs055

Papalia, D.E., \& Olds, S.W. (1995). Human Development. 6th. Ed. New York: McGraw-Hill.

Roan, L., Strong, B., Foss., P., Yager, M., Gehlbach, H., \& Metcalf, K. 2009. Social Perspective Taking. Arlington: United States Army Research Institute.

Roche, B., Barnes-Holmes, Y., BarnesHolmes, D., Sewart, I., dan O'Hara, D. (2002). Realational Frame Theory: A New paradigm for Analysis of Social behavior. The Behavior Analyst, 25, 1, 75-91.

Segrin, C. 2009. "Social Skill Training." Dalam O,Donohue, W.T., \& Fisher, Z.E. (ed). General Principles and Empirically Supported Techniques of Cognitive Behavioral Therapy. New Jersey: John Wiley \& Sons.

Selman, R. L. (1980). The growth of interpersonal understanding: 
Developmental and clinical analyses. New York: Academic Press.

Selman, R.L., \& Schultz. L.H. (1990) Making friend in youth: Developmental theory and pairtherapy. Chicago, IL: University of Chicago Press.

Selman, R.L. (2003). The promotion of social awareness: Powerful lesson from the partnership of developmental theory and classroom practice. New York: Russel Sage Foundation.

Schultz, L.H., \& Selman, R.L. (1989). Bridging the gap between interpersonal thought and action in early adolescence. The role of psychodinamic processes. Development and Psychopathology, 1,133-152.

Steedley, K.M., Schwartz, A.S., Levin, M., \& Luke, S.D. (2011). Social skills and academic acheveent. Evidence for Education, Vol. III, Issue 2.

Steen, T. \& Veen S.V. th. Teaching perspective Taking: Why It's Important - How it Might be Done. Holland: Departement of Economics, management, and Accounting Hope College.
Thompson, C.L., Rudolph, L.B., \& Anderson, D. (2004). Counseling Children. 6th. Ed. Australia: Thompson, Brook/Cole.

Trotchell, R., Loschelder, D.D., Huffmeier, J., \& Schwartz. K. (2011). Perspective taking as mans to overcome motivastional barriers in negotiations: when putting oneself into the opponent's shoes helps to walk toward agreements. Journal of Personality and Social Pathology, 4, 771-790.

Weyant, J.M. (2007). Perspective Taking as a Means of Reducing Negative Stereotyping of Individuals Who Spak English as a Second Language. Journal of Applied Social Psychology, 2007, 37, 4, pp. 703-716.

Wu, S., \& Keysar, B. (2007). The effect of culture on perspective taking. Association for psycholical science, 2007, Vol. 18, No. 7, p. 600-606.

Zeng Li. (2011). Perspective Taking as a Moderator of the Relationship between Social Rejection and Altruism. International Journal of Psychological Studies, Vol. 3, No. 2, December 2011, pp. 64-75. 